\title{
Effect of Fluorosis on Hepatic Enzymes in Human
}

\author{
Suman Chatterjee ${ }^{1 *}$, Prasanta Sinha Mahapatra ${ }^{2}$, Phalguni Chakrabarti ${ }^{3}$, \\ Pinaki Sarkar ${ }^{4}$ \\ I ( P.G.T., Department of Biochemistry, B.S. Medical College, Bankura,West Bengal ,India) \\ ${ }^{2}$ (Assistant Professor, Department of Biochemistry, B.S. Medical College, Bankura, West Bengal ,India) \\ ${ }^{3}$ (Assistant Professor, Department of Biochemistry, B.S. Medical College, Bankura, West Bengal ,India) \\ ${ }^{4}$ (Professor and H.O.D., Department of Biochemistry, B.S. Medical College, Bankura, West Bengal ,India)
}

\begin{abstract}
Fluorosis is a major public health problem in India. This cross-sectional observational study has been conducted in the fluoride endemic zones of Bankura district to evaluate the effect of fluorosis on the liver enzymes. This study was carried out in the Simlapal block of Bankura, on 100 subjects by using simple random sampling in which 50 were cases. The serum samples were collected from the subjects and serum fluoride was estimated by Ion-Meter and serum ALT, AST, ALP and LDH levels were determined by auto-analyzer and were compared with age and sex matched controls. The serum fluoride was found to have a statistically significant relationship with AST and ALP and serum $L D H$ has also statistically significant relationship with ALT and AST in the study group. The serum levels of fluoride, ALT, AST, ALP and LDH were higher in the study group compared to the comparison group.
\end{abstract}

Keywords: Serum ALT, AST, ALP, fluoride, $L D H$.

\section{Introduction}

Fluorine is one of the most abundant elements in nature and being so reactive, it is never found in its elemental gaseous form, but only in combined form. About $96 \%$ of the fluoride in the body is found in bones and teeth. Fluoride is essential for the normal mineralization of bones and dental enamel. Fluorosis is an important public health problem in 24 countries, including India ${ }^{1}$. Endemic fluorosis resulting from high fluoride concentration in groundwater is a public health problem in India ${ }^{2}$. India was one of the worst fluorosis affected countries, with large number of people suffering from it. This is because a large number of Indians depends on groundwater for drinking purposes and water at many places is rich in fluoride ${ }^{3}$. World Health Organization (WHO) has set the upper limit of fluoride concentration in drinking water at $1.5 \mathrm{mg} / \mathrm{L}^{4}$, and the Bureau of Indian Standards , has laid down as $1.0 \mathrm{mg} / \mathrm{L}$ as the maximum permissible limit of fluoride with further remarks as " lesser the better" ${ }^{2}$. Intake of fluoride higher than the optimum level is the main reason for fluorosis. Fluorine is often called as two-edged sword. Prolonged ingestion of fluoride through drinking water in excess of the daily requirement is associated with dental, skeletal and non-skeletal fluorosis. Similarly, inadequate intake of fluoride in drinking water is associated with dental caries ${ }^{6}$. In Bankura district of West Bengal out of 22 blocks 17 blocks are fluoride endemic zones, leading to consumption of high levels of fluorides in drinking water with its health consequences, i.e. high incidence of dental and skeletal and non-skeletal fluorosis symptomatic cases ${ }^{7}$. The source of this high fluoride concentration in water of Bankura district of West Bengal is supposed to be high fluoride content of the underlying hard rocks and also high fluoride content of the sedimentary assemblage of Older Alluvium comprising admixtures of sand, silt and clay, laterites, weathered morrum and caliche nodule impregnations ${ }^{8}$.

Fluoride intake in high doses has toxic effects on various organs like liver, kidney bones endocrine system etc. Histopathological disorders were observed on the slides prepared from the liver specimens of the animals exposed to chronic fluorosis. Hyperemia, local necrosis, hydropic degeneration, vacuolar degenerations, and swelling on hepatocytes around the central vein were detected ${ }^{9}$. Liver is the main organ for fluoride detoxification and, therefore, is highly susceptible to the fluoride intoxication. Various studies demonstrated that elevated levels of serum hepatic and renal enzymes have been found following fluoride intoxication indicating degenerative and inflammatory damages to the liver ${ }^{10,11,12}$. The increase in ALP, AST and ALT was due to the degeneration and necrosis of liver cells. A study conducted by Michael et al. in human for investigating the effect of high dose of fluoride intake from drinking water on some soft tissues reported that high levels of fluoride disturbs the normal ALT and AST values ${ }^{13}$. The elevated ALP, AST, ALT is an indication of the impairment of liver functions.

The aim of the study is to evaluate the relationship between serum fluoride level and the hepatic enzymes to predict the liver damage in population residing in the fluoride endemic area. 


\section{Materials and Methods}

2.1. Study area: The study areas were selected on the basis of fluoride content in water. The selected areas have a fluoride content of above $3 \mathrm{ppm}$ and the rates of dental and skeletal fluorosis are high. This cross-sectional descriptive study was carried out in Simlapal block of Bankura district. The biochemical analysis was done in the department of Biochemistry, B.S. Medical College, Bankura (District fluorosis detection laboratory).

2.2. Study subject: 50 subjects were selected by simple random sampling among them 27 were male and 23 were female. In that block, the endemic fluorosis was diagnosed according to the clinical diagnosis criteria, as described by Wang et $\mathrm{al}^{14}$. The criteria for study are (1) people living in the endemic fluorosis region since birth, (2) having mottled tooth enamel, indicating dental fluorosis, (3) consuming water with fluoride levels above 1.2 $\mathrm{mg} / \mathrm{L}$ (normal $1 \mathrm{mg} / \mathrm{L}$ ), and (4) a urine fluoride level greater than $1.5 \mathrm{mg} / \mathrm{L}$. Subjects living in the same area without showing above mentioned signs were selected as control.

The test and the control subjects were screened using a detailed questionnaire, history and physical examination. They were physically examined and information pertaining to demographics, nature of illness was collected from them using a predesigned and pretested questionnaire. Informed consent was taken from them. The study design was approved by institutional ethical committee.

2.3. Study Period: This study was carried out during the period from January 2016 to March 2016. 2.4. Laboratory investigations: The serum samples were collected from the 50 cases and 50 controls and stored at $-20^{\circ} \mathrm{C}$ before analyzing after doing centrifugation. Serum fluoride level was estimated by Ion Meter (ORION-9609BNWF) and serum ALT, AST, ALP and LDH levels were estimated by auto-analyzer (DS-302).

2.5. Statistical analysis: The data were compiled in MS excel and analyzed by different statistical methods. Data display was done by charts and tables. Data were described by proportion, mean, SD, range etc. Statistical tests like independent ' $\mathrm{t}$ ' test, Spearman correlation coefficient ( $r$ ) etc. were used to explore the relationship between variables. $\mathrm{P}$ value of $<0.05$ was considered significant to discard the null hypothesis at $5 \%$ precision and $95 \%$ confidence interval.

\section{Results}

Out of 100 participants 49 were female and rest were male. (Fig.1).

The average age of the participants was $36.42 \pm 4.95$ (mean \pm SD) years with a range of 50 years. The study group was found to have higher average serum ALT, AST, ALP and Fluoride levels compared to that of the comparison group and the difference was statistically robust (Table-1).

The serum fluoride was found to have a statistically significant positive linear relationship with AST and ALP among the subjects belonged to the study group (Table-2)

\section{Discussion}

India is one of the worst fluorosis affected country, with large number of people sufferings from it. Flurosis is a major health problem in many parts of the world. W.H.O. reported that concentrations of fluoride present in ground water are high in India and China ${ }^{15}$. As a site of very active metabolism, the liver is especially susceptible to fluoride toxicity ${ }^{12}$. Some animal and epidemiological studies showed that exposure to excessive fluoride could induce damage to the liver ${ }^{16}$. Furthermore, some animal experiments revealed that a significant dose-effect relationship was detected between water fluoride levels and damage to the liver functions ${ }^{17}$.

The normal upper limit of fluoride in urine is $0.1 \mathrm{mg} / \mathrm{l}$ and normal upper limit for fluoride in serum is $0.02 \mathrm{mg} / \mathrm{l}^{18}$ and the normal reference level of serum ALT,AST,ALP and LDH are $<45 \mathrm{U} / \mathrm{L}$ in male and $<34 \mathrm{U} / \mathrm{L}$ in female, $<35 \mathrm{U} / \mathrm{L}$ in male and $<31 \mathrm{U} / \mathrm{L}$ in female, 53-125 U/L and 125-220U/L respectively ${ }^{19}$.

A study done by Pratheebaa P. et al showed that the enzymes ALT and ALP were positively correlated with the occurrence of fluoride, while AST, LDH, were negatively correlated with the existence of fluoride ${ }^{20}$.

A cross-sectional study conducted by Xiong X et al suggested that excessive (i.e. $42.0 \mathrm{mg} / \mathrm{L}$ ) fluoride in drinking water may cause damage to children's liver functions, which would aggravate as drinking water fluoride level increases $^{21}$.

It remains controversial about whether or not excessive fluoride intake induces damage to human liver functions. In a study done by Michael et al. showed that fluoride may disturb protein synthesis and elevate the activities of ALT and $\mathrm{AST}^{13}$. In a study, done by Shivashankara et al., various serum indexes about liver functions were found abnormal in children with skeletal fluorosis ${ }^{10}$. However, some reports do not support this fact. The study conducted by Liang et al. on the liver functions including TP, ALB, AST, total bilirubin of individuals from six different fluoride contents in drinking water found no significant changes ${ }^{22}$. Even though residing in areas with water fluoride concentration was between 1.5 and $23.0 \mathrm{mg} / \mathrm{L}$, no damage to liver functions was observed in residents ${ }^{23}$. 


\section{Conclusion}

Our study suggested that the increased serum fluoride concentration can damage liver resulting in increase in liver enzymes. Hence general awareness should be generated to the people for using fluoride free drinking water and further studies are to be required for establishing the relationship between liver function and the fluorosis.

\section{References}

[1]. Saravanan S, et.al Prevalence of dental fluorosis among the primary school children in rural area of Chidambaram Taluk, Cuddalore District, Tamil Nadu. India. Indian J Commun Med .2008;33:146-50.

[2]. Kotecha PV, Patel SV, Bhalani KD, Shah D, Shah VS, Mehta KG. Prevalence of dental fluorosis \& dental carries in association with high levels of drinking water fluoride content in a district of Gujrat, Indian J Med Res. 2012;135(6):873-77.

[3]. https://www.novapublishers.com/catalog/product_info.php?product_id=15895.

[4]. Andezath SK, et.al. Fluorosis management in India: the impact due to networking between health and rural drinking water supply agencies. JAHS-AISH Publications.2000;260:159-65.

[5]. Guidelines for drinking water quality.Geneva: $\quad$ Who; $2004 \quad$ world Organizationhttps://www.novapublishers.com/catalog/product info.php?products id=15895.

[6]. Park K.Park text book of preventive and social medicine.Ed21 Banarasisdas Bhanot Publishers, 1167.Prem nagar, Jabalpur India.2011.p577.

[7]. National Programme For Prevention And Control of Fluorosis Bankura -Inter departmental Sensitization on Fluorosis ....issued from CMOH Office Bankura on 08.04.15.

[8]. Chakrabarti S. et. al. Fluoride Contamination in The Groundwater of Bankura District, West Bengal : A Hydrogeo - Environmental Appraisal. Journal of Indian Water Works Association .April- June $2012: 134-42$.

[9]. Ersan Y, Koç E, Ari I, Karademir B. Histopathological effects of chronic fluorosis on the liver of mice (Swiss albino). Turk J Med Sci.2010; 40 (4): 619-22.

[10]. Shivashankara, A., Y. S. Shankara, S. H. Rao, and P. G.Bhat (2000). A clinical and biochemical study of chronic fluoride toxicity in children of KheruThanda of Gulbarga district, Karnataka, India. Fluoride; 33(2):66-73.

[11]. Shashi, A. and S. Thapar (2001). Histopathology of fluoride-induced hepatotoxicity in rabbits. Fluoride; 34(1):34-42.

[12]. Wang, W. and Y. Li (2002). Environmental epidemiology of fluorine and its effects on health. Soil Environ. Sci.; 11(4):383-87.

[13]. Michael, M., V. V. Barot, and N. Chinoy (1996). Investigations of soft tissue functions in fluorotic individuals of North Gujarat. Fluoride;29:63-71.

[14]. Y. Wang, Y. Yin, L.A. Gilula, A.J. Wilson, "Endemic fluorosis of the skeleton: radiographic features in 127 patients". American journal of Roentgenology 1994, 162:93-98. patients”. American journal of Roentgenology. 1994; 162:93-8.

[15]. World Health Organization (WHO): Fluorides. Geneva: World Health Organization, 2002.

[16]. Wang, J., Zheng, ZA., Zhang, LS., Cao, DM., Chen, KZ., Lu, D., 1993. An experimental study for early diagnostic features in fluorosis. Fluoride 26, 61-5.

[17]. Liu QZ., Cui RP., Hua HG., Yang DH. Study on mechanisms and locations of kidney injuries in rats induced by chronic fluorosis. Chin. J. Pub. Health.1994; 13: 236-8.

[18]. Susheela AK, Bhatnagar M, Vig K, Mondal NK. Excess fluoride ingestion and thyroid hormone derangements in children living in Delhi, India. Fluoride .2005;38:98-108.

[19]. Burtis CA, Burns DE. Tietz Textbook of Clinicla Chemistry and Molecular Diagnostic.Elesevier; 2012.

[20]. Pratheebaa P et al, Fluoride Toxicity in Humans: Effect on Serum and Plasma Enzyme Levels in Endemic Areas of Krishnagiri District of Tamilnadu, India. Journal of Life Medicine.July 2013; Volume 1, Issue 2: 33-7.

[21]. Xiong X et al. Doseeffect relationship between drinking water fluoride levels and damage to liver and kidney functions in children. Environ Res. 2007 Jan;103(1):112-6

[22]. Liang CH., Li WH., Zhang SH., Wu YB., Ma F., Katz, BP., Brizendine, EJ.B., Stookey, GK. Analyses of blood chemistry and electrolytes of human exposure to fluoride in drinking water. Chin. J. Pub. Health.1999; 15: 34-6.

[23]. Wan GM., Mo ZY., Liu ZJ., Chen Z., Tong JD., Zhao RL. Determination and analysis on multimark of test of patients with endemic fluorosis. Chin. J. Endem.2001; 20:137-39.

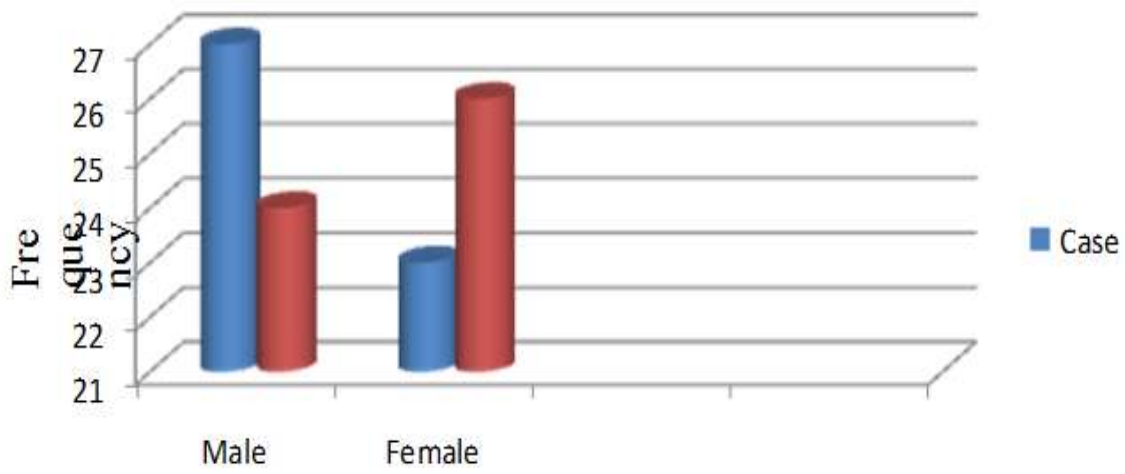

Figure-1: Distribution of study subjects according to gender 
Table No-1: Serum Levels Of ALT, AST, ALP, LDH And Fluoride In Cases And Control

\begin{tabular}{|l|l|l|l|l|l|}
\hline SI.No & Enzymes & $\begin{array}{l}\text { Control }(\mathbf{n}=\mathbf{5 0}) \\
\text { Mean } \pm \text { SD }\end{array}$ & $\begin{array}{l}\text { Fluorosis subject(n=50) } \\
\text { Mean } \pm \text { SD }\end{array}$ & $\boldsymbol{P}$ Value & Significance \\
\hline 1 & ALT (U/L) & $35.69 \pm 0.56$ & $44.56 \pm 3.38$ & 0.000 & Highly Significant \\
\hline 2 & AST (U/L) & $33.35 \pm 1.45$ & $38.18 \pm 1.55$ & 0.242 & Insignificant \\
\hline 3 & ALP (U/L) & $105.21 \pm 10.96$ & $328.02 \pm 78.76$ & 0.000 & Highly Significant \\
\hline 4 & LDH (U/L) & $193.99 \pm 25.34$ & $376.18 \pm 83.94$ & 0.000 & Highly Significant \\
\hline 5 & $\begin{array}{l}\text { Serum Fluoride } \\
(\mathrm{mg} / \mathrm{L})\end{array}$ & $0.0398 \pm .0069$ & $0.2496 \pm .0266$ & 0.000 & Highly Significant \\
\hline
\end{tabular}

**. Correlation is significant at the 0.01 level (2-tailed).

Table No-2: Relationship between the serum parameters among study group

\begin{tabular}{|l|l|l|l|}
\hline Parameter & Group & $\begin{array}{l}\text { Correlation } \\
\text { coefficient (r) }\end{array}$ & $\begin{array}{l}\text { Significance } \\
\text { (p value) }\end{array}$ \\
\hline Serum fluoride Vs ALT & Study & 0.088 & 0.543 \\
\hline Serum fluoride Vs AST & Study & $0.642^{* * *}$ & 0.000 \\
\hline Serum fluoride Vs ALP & Study & $-0.490^{* *}$ & 0.000 \\
\hline Serum fluoride Vs LDH & Study & 0.203 & 0.157 \\
\hline Serum ALT Vs AST & Study & 0.077 & 0.594 \\
\hline Serum ALT Vs ALP & Study & 0.138 & 0.338 \\
\hline Serum ALT Vs LDH & Study & -0.130 & 0.367 \\
\hline Serum AST Vs ALP & Study & -0.056 & 0.700 \\
\hline Serum AST Vs LDH & Study & $0.612^{* *}$ & 0.000 \\
\hline Serum ALP Vs LDH & Study & $0.307^{*}$ & 0.030 \\
\hline
\end{tabular}

*. Correlation is significant at the 0.05 level (2-tailed). 